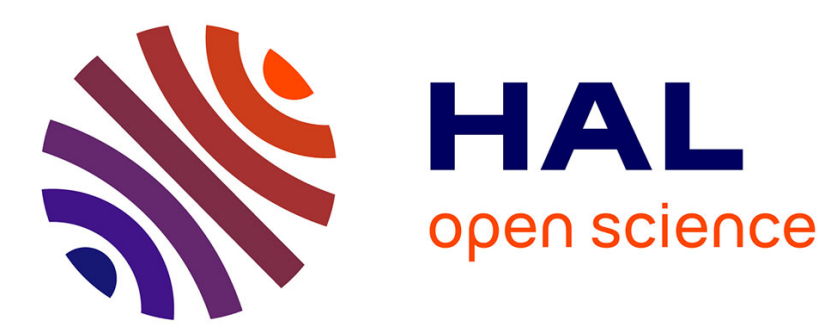

\title{
External economies as a mechanism of agglomeration in EU manufacturing
}

Nuria Domeque Claver, Carmen Fillat Castejón, Fernando Sanz Gracia

\section{To cite this version:}

Nuria Domeque Claver, Carmen Fillat Castejón, Fernando Sanz Gracia. External economies as a mechanism of agglomeration in EU manufacturing. Applied Economics, 2011, pp.1. 10.1080/00036846.2011.589824 . hal-00719068

\section{HAL Id: hal-00719068 https://hal.science/hal-00719068}

Submitted on 19 Jul 2012

HAL is a multi-disciplinary open access archive for the deposit and dissemination of scientific research documents, whether they are published or not. The documents may come from teaching and research institutions in France or abroad, or from public or private research centers.
L'archive ouverte pluridisciplinaire HAL, est destinée au dépôt et à la diffusion de documents scientifiques de niveau recherche, publiés ou non, émanant des établissements d'enseignement et de recherche français ou étrangers, des laboratoires publics ou privés. 


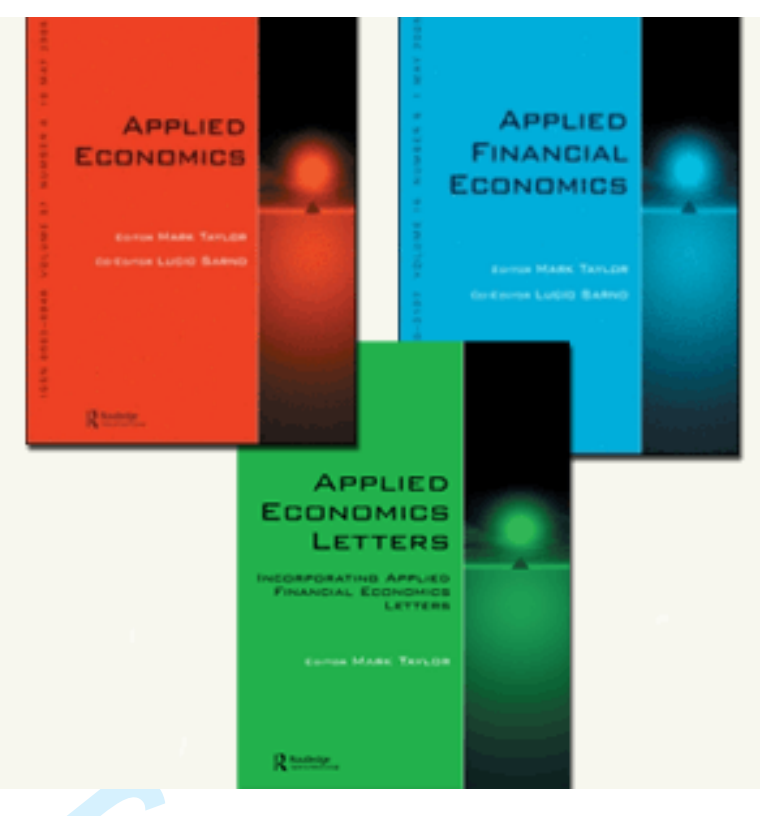

\section{External economies as a mechanism of agglomeration in EU manufacturing}

\begin{tabular}{|r|l|}
\hline Journal: & Applied Economics \\
\hline Manuscript ID: & APE-2010-0519 \\
\hline Journal Selection: & Applied Economics \\
\hline Author: & 11 -Nov-2010 \\
\hline Complete List of Authors: & $\begin{array}{l}\text { Domeque Claver, Nuria; University of Zaragoza, Structure and } \\
\text { Economic History and Public Economy } \\
\text { Fillat Castejón, Carmen; University of Zaragoza, Structure and } \\
\text { Economic History and Public Economy } \\
\text { Sanz Gracia, Fernando; University of Zaragoza, Economic Analysis }\end{array}$ \\
\hline JEL Code: & $\begin{array}{l}\text { F14 - Country and Industry Studies of Trade < F1 - Trade < F - } \\
\text { International Economics, O14 - Industrialization; Manufacturing; } \\
\text { Service Industries; Tech Choice < O1 - Economic Development < O } \\
\text { - Economic Development, Technological Change, and Growth, O47 - } \\
\text { Measurement of Economic Growth|Aggregate Productivity < O4 - } \\
\text { Economic Growth and Aggregate Productivity < O - Economic } \\
\text { Development, Technological Change, and Growth, R12 - Size and } \\
\text { Spatial Distributions of Regional Economic Activity < R1 - General } \\
\text { Regional Economics < R - Urban, Rural, and Regional Economics }\end{array}$ \\
\hline Keywords: & $\begin{array}{l}\text { External economies, Economies of agglomeration, Geography, } \\
\text { Productivity, EU countries }\end{array}$ \\
\hline
\end{tabular}




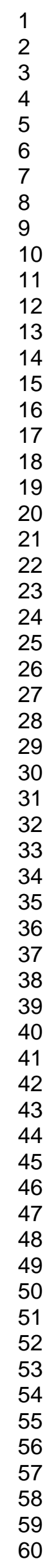

SCHOLARONE ${ }^{\text {m }}$
Manuscripts

10

12

13

14

15

16

18

19

20

22

23

25

26

27

29

32

33

34

35

36

39

40

41

42

44

45

46

47

48

50

51

52

53

54

56

57

58

60

Editorial Office, Dept of Economics, Warwick University, Coventry CV4 7AL, UK 


\title{
TITLE PAGE
}

\section{DATA FROM THE AUTHORS}

\section{External economies as a mechanism of agglomeration in EU manufacturing}

N. Domeque Claver ${ }^{\mathrm{a}^{*}}$, C. Fillat Castejón ${ }^{\mathrm{b}}$ and F. Sanz Gracia ${ }^{\mathrm{c}}$

\author{
${ }^{a}$ Department of Structure and Economic History and Public Economy, University of Zaragoza. Plaza de \\ la Constitución s/n, 22001 Huesca, España. Tel.: +34 976239373 ext. 3277; fax: +34 976239375 b \\ Department of Structure and Economic History and Public Economy, University of Zaragoza. Gran Vía \\ 2, 50005 Zaragoza, Spain \\ ${ }^{c}$ Department of Economic Analysis. Gran Vía 2, 50005 Zaragoza, Spain \\ *Corresponding author. E-mail: ndomeque@unizar.es
}

\begin{abstract}
Productive externalities are significant determinants of agglomeration, not deeply studied at the industry and international level. We analyse the impact on productivity growth of technological externalities, both inter- and intraindustry, national or international, at the industry level for the European Union (EU) countries and the period 1995-2002. The results confirm the advisability of considering international externalities when countries are takes as regions, whose omission underestimates national spillovers. Together with national endowments and a central geographical position, the growth of productivity is encouraged by national and international specialization as a general result; moreover, it is fuelled by stronger interindustry spillovers and productive diversification, a result more evident for high technology industries, while lower technology industries are more sensitive to the omission of international externalities. Economic integration seems to be relevant, because supranational regions with less friction for goods and factor movements are more likely to take advantage of external economies as a mechanism of productivity growth and agglomeration.
\end{abstract}




\section{External economies as a mechanism of agglomeration in EU manufacturing}

\section{Introduction}

An essential reason for the geographic concentration of an industry is the existence of increasing returns in the individual production function, besides which, the Marshallian tradition of economic analysis has emphasised the positive effects of externalities on the productivity of companies. One type of externalities are known as economies of agglomeration, which mainly occur with expensive transport costs, and begin a trend towards grouping new companies in the nearest geographical area, leading to a self-reinforcing process of industrial localisation (Hoover 1937; Weber 1929). Agglomeration is fuelled by geographical proximity and the flow of knowledge, so important spillovers should be expected between neighbouring regions. Definitively, externalities give rise to agglomeration processes whose mechanisms have obvious effects on industry productivity.

The purpose of this research is, indeed, to analyse the existence of productive externalities in industry and their effect on productivity as an agglomeration mechanism. The existing evidence is scarce and comes from studies at the regional level or focused on individual countries or industries. This work approaches an analysis desegregated by industrial activity and in the economic context of an integrated market such as the EU, a contribution in itself. Indeed we hypothesize that, for a supranational region, both national and international externalities should be analysed simultaneously, because both have a role on productivity growth and omitting the international dimension of spillovers can skew the effect of the national one. Starting from the theoretical foundation which gathers pecuniary externalities in the production function, we also consider knowledge spillovers by means of what have been called external economies of specialization and of diversity within each country. And the main contribution in our analysis is to add the international dimension to the technological externalities between countries, which are introduced in two ways. On one hand, the international specialization of each country in each activity is a source of additional externalities, besides the commonly used national specialization. On the other, the peripherality of the country 
is considered, given that the effects of international externalities may be weaker on the activity of a distant country. Thus, this paper estimates a production function for each industry, using an international data panel, segregating countries, years and sectors, in order to determine the impact of national and international externalities and of geography on productivity growth in every industry in the EU.

Perhaps a central country, which supports low transport costs and enjoys a diversified international economic environment, can become specialized in some industry; but a country more or less isolated on the periphery needs to have a dynamic and diversified industry to get a higher productivity growth. And we might not see its relevance unless we consider this country in a supranational economic context.

The paper is structured as follows: first, the basic theoretical foundations of externalities in production are reviewed, as are recent studies which have investigated the relationship between externalities, economies of agglomeration and productivity. Second, we propose an empirical model of productivity growth with national and international externalities which will be tested for the EU countries and industries. Third, the results obtained are discussed and are followed by a discussion about the appropriate nature of supranational regions for this analysis; finally, we sum up the conclusions derived from the analysis.

\section{External economies in production: theoretical foundations and empirical evidence}

From the origins of the literature on externalities in production, in the contribution of Marshall (1923), different typologies have been formulated and connections established with the New Economic Geography and Regional and Urban Economics ${ }^{1}$. Essentially, spatial concentration of economic activity can create advantages in production through two main channels. First, the existence of agglomerations of companies favours the establishment of other complementary activities supplying specialised inputs, goods and services for each sector, generating forward and backward interindustry linkages. And second, the flow of technological information related to specific knowledge which is shared by the companies within a sector and enables a cumulative process of improvement in production, called intraindustry knowledge spillovers. Later,

\footnotetext{
${ }^{1}$ For an exhaustive review, see Rosenthal and Strange (2004) or Duranton and Puga (2004).
} 
Scitovsky (1954) described the former type as pecuniary and the latter as technological; and Regional and Urban Economics stresses the static nature of the pecuniary ones, and the dynamic externalities related to the diffusion of knowledge and its influence on the growth of an activity.

The different typologies of dynamic and external effects may be theoretically satisfactory but turn out to be highly ambiguous in practice, as the size and growth of an activity are closely related, and are at once cause and effect of a single phenomenon. Their endogenous nature is highlighted in the concept of economies of agglomeration in the New Economic Geography, according to which there is a trade-off between two opposing forces - externalities against transaction costs such as transport cost or economic peripherality - which act on economic productivity and begin a cumulative process between productivity and agglomeration.

There is mixed evidence in the literature on the part played by externalities and by geography in productivity, with pronounced heterogeneity in the analysed countries or sectors. Most studies related to Regional and Urban Economics highlight how productivity increases with the size of the industry itself (economies of localisation, outside the company but within the industry) or with the size of the region (economies of urbanisation, outside the company and the industry, but within the region). Nakamura (1985) proves how the larger industries in Japan receive more productive advantages from economies of localisation, while small industry benefits especially from economies of urbanisation. We can also mention Moomaw (1998) for the USA and Dogan (2001) for Turkey, remarking on the importance of economies of urbanisation. Finally, in other works like Lall et al. (2004), even including infrastructures facilitating access to markets in India, market size of the region does not appear to play a significant part.

Some authors go further and attempt to identify the relationship that exists between economies of agglomeration, the type of industries that become localised and the characteristics of the regions where they do so. Thus, Feser (2001) and Henderson (1986) identify high technology industries as those that present the most intense economies of localisation in the USA. Henderson (1986, 1997 and 2003) underlines the strong correlation between these economies of localisation and specialization instead of diversity in the regions where they localise. 
The same result is emphasised by De Lucio et al. (2002) in their analysis of productivity growth by sector and Spanish province, following Martin and Ottaviano (1996), obtaining evidence of technological spillovers when there is a high degree of specialization. Also, Partridge and Rickman (1999) find that, in the industrial sector for the US states, specialization more than diversification yields a higher labour productivity growth. Serrano (2000) gives an interpretation when analyses the impact of external technological externalities in the Spanish regions for agriculture, energy, industry and services: diversity increases the differential in regional productivity growth and a maturing period is required to make the externalities evident, while specialization economies have a notably positive contemporaneous impact. Only Glaeser et al. (1992) finds that the impact of diversification is much larger, and he associates larger industries to larger regions; but in all papers there is general evidence of the effect of interindustry externalities on productivity growth.

To sum up, the evidence in existing literature reveals the significant importance of the size of the industry itself on economic productivity, as well as the specialization or diversification of a region, aspects linked in turn with technological spillovers, and which we consider to be of central relevance in our own analysis. A main hypothesis in our paper is that these externalities, usually restricted to the regional level within a country, can be found as a mechanism of agglomeration also at the international level, and this is more evident when the international dimension of externalities is also considered. In Puga (2009) we can see a review about the evidence, magnitude and causes of agglomeration economies where externalities play a major role.

In an international context, considering countries as regions, mainly interindustry pecuniary spillovers have been studied. In this line, Caballero and Lyons $(1990,1992)$ obtain significant evidence of national and international pecuniary externalities on productivity in four EU countries, both sectoral and aggregated. Henriksen et al., (2001) carry out a similar analysis to that of Caballero and Lyons also in four EU countries, but they add externalities between clusters, interindustry national and international intraindustry externalities; the high technology cluster shows more national externalities and the international ones are evident in transport. Following Henriksen et al. (2001), Midelfart-Knarvik and Steen (2002) analyse the Norwegian maritime sector using a production function with the size and growth of the supply sectors as a 
proxy of externalities towards the maritime cluster, obtaining evidence that vertical links reinforce agglomeration. In the same way, we also include theses interindustry externalities in our international analysis.

Finally, the geographical dimension of technological externalities is introduced in a number of studies, mainly Smith (1999), Graham (2000), Ciccone (2002), Feser (2002), Davis and Weinstein (2003), Cohen and Paul (2005) and Amiti and Cameron (2007). This literature emphasises that proximity is important for the flow of know-how, so that we should expect knowledge spillovers are particularly important for countries in a central geographical position.

Spatial externalities are identified by Graham (2000) through employment density between regions in UK but the results do not show a significant influence on variation in productivity. Evidence from spatial externalities is found by Ciccone (2002) for the European regions (NUTS 3) using production density, but there is no evidence for countries. For the US economy, Smith (1999) confirms the interindustry and interstate spillovers. Moreover, Cohen and Paul (2005), for the US and food processing industry, find costs economies from production density in own and neighbour regions; again these economies are lower at the State wider level.

Distance, as the most intuitive geographical component, considers three possible sources of externalities, following Feser (2002): the possible supply of intermediate inputs, approximating the distance to supply regions; the availability of specialised labour, which measures access to a specialised labour market; and the total spending on research carried out by the universities, which approximates knowledge externalities.

Amiti and Cameron (2007) use information on the location of input suppliers in Indonesia to show that the benefits of proximity to suppliers and their relationship with distance. They measure the effect of technology spillovers by proximity to other firms in the same industry in every district, distance adjusted. The more firms in close proximity with related technology, the more likely is that firms can learn from each other.

The impact of a potential market on Japanese regions together with cost and demand linkages and the existence of intraindustry and international externalities are analysed by Davis and Weinstein (2003), 
although distance is not a determinant in this case. Thus, given a definition of region or country, distance considered by some indicator of economic activity is considered a good instrument for analysing the impact of geography in the relationship between externalities and productivity, and so we will use the same focus in our analysis.

Tu sum up, in a survey paper, De Groot, Henri L. F; Poot, Jacques; Smit, Martijn J. (2009) collect a theoretical perspectives on agglomeration externalities and growth and a number of recent empirical literature on agglomeration and growth. The chapter evaluates the statistical robustness of evidence for externalities presented in 31 scientific articles, all building on the seminal work of Glaeser et al (1992).

\section{An empirical model on productivity growth with national and international externalities}

The base of our analysis takes as its starting point the production function, in line with the work of MidelfartKnarvik and Steen (2002), Serrano (2000) or De Lucio et al. (2002). Together with factor endowments, we include the sources of externalities indicated in the previous section, with special emphasis on technological externalities, besides introducing the effect of economic geography. Starting with the premise that agglomeration affects the total productivity of the factors and that this in its turn affects output, we will analyse the existence of externalities on the growth rate of labour productivity by sectors. Among the externalities which we consider in the production function, we first take into account the national ones, where we distinguish between those coming from other industries - interindustry - and those within the industry itself; then we add to the analysis the effect of international externalities.

If we consider a production function of the Cobb Douglas type:

$$
Q_{i, c}=A_{i, c} K_{i, c}^{\alpha} L_{i, c}^{1-\alpha}
$$

where $Q_{i, c}$ is the gross value added at market prices, $\mathrm{K}$ is the gross capital stock, $\mathrm{L}$ is employment, $\alpha$ measures the degree of scale returns, $\mathrm{c}$ is the country and $\mathrm{i}$ the productive sector. We use the same equation in relative terms, and thus obtain an expression of the productivity of labour, 
$\left(\frac{Q}{L}\right)_{i, c}=A_{i, c}\left(\frac{K}{L}\right)_{i, c}^{\alpha}$

Taking differences in logarithms,

$$
\log \left(\frac{Q}{L}\right)_{i, c}=\log A_{i, c}+\alpha \log \left(\frac{K}{L}\right)_{i, c}
$$

Given that we are interested in looking for the effects of dynamic externalities in the productivity growth rate, we take equation (3) in growth rates,

$$
\Delta \log \left(\frac{Q}{L}\right)_{i, c}=\Delta \log A_{i, c}+\alpha \Delta \log \left(\frac{K}{L}\right)_{i, c}
$$

which is equivalent to

$$
g_{P v L i, c}=g_{T F P i, c}+\alpha g(K / L)_{i, c}
$$

Thus we have the labour productivity growth rate $\left(g_{P v L i, c}\right)$ on the left of the equation, measured as gross value added (VA) per worker, and on the right the total factor productivity growth rate and the growth rate of their use, respectively. So, $g(K / L)_{i, c}$ is the relative factor endowment growth rate measured by the capital/labour ratio. The urban and regional areas of greatest economic size have a greater ratio which in turn is associated with higher levels of technology and human resources. Thus, there is both a spatial and a sectoral association between factor endowments and productivity. Therefore, we expect the coefficient associated with this variable to have a positive value.

Externalities have an effect on the use of productive factors, which means an impact on the total productivity of the factors and thus on output and labour productivity. For this reason we suppose that this productivity depends on technological externalities, both interindustry and intraindustry, national or international. 
$T F P_{i, c}=f\left(\widetilde{q}_{j, c}, S_{i, c}, D_{i, c}, E_{i, c}\right)$

where $\widetilde{q}_{j, c}$ approximates national interindustry externalities;

$S_{i, c}$ approximates the national intraindustry externalities derived from specialization of activity in sector i;

$D_{i, c}$ approximates the national interindustry externalities, in this case due to the productive diversification of the country;

$E_{i, c}$ approximates the international intraindustry externalities;

We go on to explain how each of these variables is measured, and according to theory, the hypothesis on its behaviour.

$\widetilde{q}_{j, c}$ is the output variation of country $\mathrm{c}$ in all sectors $\mathrm{j}$ different to $\mathrm{i}$ within the country, and we expect a positive impact on productivity. This behaviour is due to the economies that can be obtained in large scale production. Increases in the size of markets permit greater specialization which is reflected in productivity increases, while a growth of the supply market reduces production costs.

$$
\widetilde{q}_{j, c}=\sum_{j \neq i} q_{j, c}
$$

Another two dimensions of national externalities are economies of specialization of intraindustry activity $\left(S_{i, c}\right)$, and interindustry economies of diversification $\left(D_{i, c}\right)$. The concentration of the country in activity i can be measured via the Herfindhal index of the proportions of each activity in the country as a whole; we opt to use the VA as a measurement of activity and proxy of innovation processes, given that we cannot distinguish which is the activity which concentrates the VA of a country, and we are interested in approximating the effects of specialization on this activity with an interaction of this coefficient with the production level itself. Thus a high value of this interaction approximates the specialization of VA in activity $\mathrm{i}$ and will be an indicator of national intraindustry externalities, which is reflected in productivity increases. 


$$
S_{i, c}=q_{i, c} \sum_{i}\left(V A_{i, c} / V A_{c}\right)^{2}
$$

We also considered distinguishing impact from other sectors using an interaction of the coefficient with production in other industries. However this has been excluded from the analysis because we could not identify the sector where the externality comes from, and in the case of a sector-by-sector interaction the degrees of freedom are enormously reduced.

A practicable alternative is to include the influence of the rest of the sectors by the diversification of industries in the country. The index of diversity $D_{i, c}$ in the country c excludes activity i from the above concentration coefficient, so we can know if the variety of other production in the country has an influence on activity i.

$$
D_{i, c}=\sum_{j \neq i}\left(V A_{j, c} / V A_{c}\right)^{2}
$$

A lower value of this index is the result of the variety of activities and a more homogenous distribution of the country's production; a greater value indicates production concentration in one of the remaining activities and perhaps less diversification. The literature supposes that greater diversification generates more productivity, as suppliers and clients are plentiful in the region, empowering interindustry linkages; thus, we expect the coefficient assigned to this variable to be negative.

The international intraindustry externalities are measured by the index of specialization of country c in activity $\mathrm{i}$ :

$$
E_{i, c}=\left(\left[\frac{V A_{i, c}}{V A_{c}}\right] /\left(\frac{V A_{i, E U}}{V A_{E U}}\right)\right)
$$

calculated in terms of VA in country $\mathrm{c}$ in the ith sector. With this variable we measure the relative size of the sector in the country compared to the average of all the EU countries, or, along similar lines, the international localisation of a given sector. It is supposed that a bigger sector in the country, or in other words a more 
specialised country, can attract new resources while increasing productivity in the existing ones. This is an additional agglomeration mechanism which feeds back to specialization and productivity growth. As such, we expect this variable to be positive.

Once the variables which approximate the externalities are defined, assuming that the total productivity growth of the factors is a multiplying function of them, we consider, as an additional international element, that geography will colour this effect, so that more distant regions will receive a smaller effect from the same externality than more central regions. A common way to monitor the effect of geography is to include an index of peripherality $\left(G_{c}\right)$ of the country receiving the externality, which weighs the distance to each country against its economic importance, and which we expect a negative value for,

$$
G_{c}=\frac{\sum_{k \neq c} d_{c, k} * D P_{k}}{N-1}
$$

where $d_{c, k}$ is the bilateral distance between two countries $\mathrm{c}$ and $\mathrm{k}, D P_{k}$ is the gross interior product and $\mathrm{N}$ is the total of countries in the sample.

Taking into account that each variable defined takes a different value each year $t$ and that there is an error term for each observation $u_{i, c, t}$, we suggest an empirical model of labour productivity growth as follows,

$$
g_{P v L i, c, t}=\alpha g_{(K / L)_{i, c, t}}+\beta_{\widetilde{q}} g_{\widetilde{q}_{j, c, t}}+\beta_{S} g_{S_{i, c, t}}+\beta_{D} g_{D_{i, c, t}}+\beta_{E} g_{E_{i, c, t}}+\beta_{G} G_{i, c, t}+u_{i, c, t}(7)
$$

The next sections estimate this model for the EU countries and explain the results, first stressing the effect on productivity growth of national and international externalities by industry, and then discussing the significant evidence of technological spillovers, in particular for supranational regions.

The statistics have come from EUROSTAT for the principal aggregates of National Annual Accounts in millions of Euros, such as Gross Value Added to basic prices, Gross Interior Product at market prices, Intermediate Consumption and Employment. The Gross Capital Stock has been obtained from the OECD STAN Structural Analysis Database 2005 Edition and the distance to large circles came from Jon 
Haveman's website ${ }^{2}$. All these data are available in the $\mathrm{EU}^{3}$ annually from 1995 to 2002 and for 13 industries, forming a total sample of 1248 observations. According to the Statistical Classification of Economic Activities (NACE) in Rev.1.1., our industries are: (1) Food products, beverages and tobacco; (2) textiles and textile products; (3) leather and leather products; (4) wood and wood products; (5) pulp, paper and paper products; publishing and printing; (6) coke, refined petroleum products and nuclear fuel; (7) chemicals, chemical products and man-made fibres; (8) rubber and plastic products; (9) other non-metallic mineral products; (10) basic metals and fabricated metal products; (11) machinery and equipment (12); electrical and optical equipment; and (13) transport equipment.

Fig. 1 shows the descriptive boxplots of productivity growth and externalities variations along time, in average and by industry. National interindustry externalities (other sectors' output) have a similar dispersion pattern across countries, lightly skewed towards medium-low values; the exceptions are coke, refined petroleum, nuclear fuel (6), with lower dynamism in other national sectors, and electrical and optical equipment (12), with less dispersion and tending towards more dynamism. The speed of national intraindustry externalities (specialization) is the most heterogeneous externality and dispersed across countries, with always some outliers with low specialization; specialization is higher in coke, refined petroleum, nuclear fuel (6) and lower in textiles and its products (2), and the more sophisticated industries seem to experience a faster specialization. National interindustry externalities (diversification) present moderate variation rates, although some sectors enjoy an increasing diversification, while others are characterized by the opposite, and there are always countries at the extremes ${ }^{4}$; electrical and optical equipment (12) stands out because of the associated dispersion in industrial diversification. Finally, international intraindustry externalities (specialization) show the slowest changes and less dispersion. Most industries share similar and moderate rates of agglomeration, with some tendency towards faster variations; in particular, the fastest agglomeration occurs in electrical and

\footnotetext{
${ }^{2}$ See "http://www.macalester.edu/research/economics/PAGE/HAVEMAN/Trade.Resources/Data/Gravity/ dist.txt".

${ }^{3}$ The widest sample available is that of Austria, Belgium, Germany, Denmark, Spain, Finland, France, Greece, Italy, the Netherlands, Portugal and Sweden.

${ }^{4}$ Sweden and Finland experience faster concentration in other industries and Greece a faster diversification. Greece also shows a slower - even negative - national intraindustry externality.
} 
optical equipment (12), transport equipment (13) and especially in coke, refined petroleum, nuclear fuel (6), where national specialization leads to international agglomeration. Finally, productivity growth is more dispersed in leather products (3), refined petroleum (6), electrical and optical equipment (12) and transport equipment (13), where a small number of countries show faster growth; its profile is striking, similar to that of national and international specialization.

\section{FIGURE 1 HERE}

\section{Empirical estimation and results for the EU countries}

The estimation of our model has been carried out sequentially, considering first variables of national character such as factor endowments and national externalities, both inter and intraindustry, and then introducing international externalities and the effect of geography. In each stage of the sequence, panel data estimation by industry tests the absence of correlation between the explicative variables and the error term; in most sectors the rejection of this hypothesis allows us to assume the existence of fixed effects and mainly, in a small sample such as ours, obtaining some unbiased estimators and the control of any possible omitted and time invariant variables. However, the estimation of the equation (7) can present a problem of endogeneity because of using the VA both in the endogenous variable and in some explicatives, and the growth of the VA by employee can determine the agglomeration of the activity reflected in concentration, diversification and specialization indices. Moreover, agglomeration is an endogenous phenomenon itself, so that endogeneity by industry has been contrasted by Hausman's test (1976). Arellano and Bond (1991) recommend the use of their Generalized Method of Moments (GMM) when the model includes endogenous or predetermined variables; this method works in differences to prevent the fixed effects and other regressors to be correlated with the residuals. But with finite samples, as it is our case, there is a problem of identification and difference-GMM yields downwards biased standard errors and inefficient estimators. To solve this, Blundell and Bond's (1998) GMM system and the Windmeijer (2005) correction for small samples are recommended; this method is used in those industries where we find evidence of endogeneity. 
In the next paragraphs, we first explain the sequence of estimations and the effects on productivity growth of national externalities, then the changes when the international externalities are introduced jointly with the national ones, and we finish this section with a discussion of the differences we might expect from an international sample which is not economically integrated in a supranational region.

National externalities and productivity growth

The relevant equation is now:

$$
g_{P v L i, c, t}=\alpha g_{(K / L)_{i, c, t}}+\beta_{\widetilde{q}} g_{\widetilde{q}_{j, c, t}}+\beta_{S} g_{S_{i, c, t}}+\beta_{D} g_{D_{i, c, t}}+\varepsilon_{i, c, t}
$$

The summary table (table 1) synthesises the variables which turn out to be significant in each case and the value of the coefficients obtained. The details of the complete estimation and the relevant statistics are in the Appendix (tables A1 and A2).

\section{TABLE 1 HERE}

The results confirm the relevance of factor endowments in practically all sectors and of national externalities of specialization and diversification, which highlights the importance of growth of national localisation of industrial activity. In all cases the signs obtained are as expected, and we can affirm that a greater endowment of capital per worker has a positive influence on productivity growth; the same effect is deduced from the growth of concentration of activity within the country and the growth of its diversification in the supply and client sectors. Only in the transport equipment industry (13) do we find that endowment factors are not relevant, but externalities are; this may indicate that the mechanisms of agglomeration and interindustry linkages propounded by the New Economic Geography play a very important part in this sector. At the same time it is noticeable that neither endowment factors nor national externalities are relevant in coke, refined petroleum products and nuclear fuel (6), logically enough if we think of our dependence on the exterior regarding these products, which leads us to think that international externalities will have more influence. 
The growth of concentration or national specialization contributes to the growth of productivity in all sectors - except, as mentioned, petrol refinery (6), and also machinery and equipment (11) - and is usually accompanied by a significant diversification of suppliers and clients within the country $\left(\mathrm{D}_{\mathrm{i}, \mathrm{c}}\right)$. Diversification in other industries contributes to productivity growth in all activities but wood and its products (4), coke and petroleum products and nuclear fuel (6) and other non-metallic mineral products (9). And interindustry linkages are only relevant for wood and its products (4), chemicals (7) and basic metals and fabricated metal products (10); the striking thing is that this effect is negative, against the hypothesis, indicating perhaps the sensitivity of these sectors to imbalances in their interindustry relationships.

Joint effect on productivity growth of national and international externalities

The second column in table 1 and table A2 of the Appendix shows the effect of factor endowments and externalities, adding the international dimension of externalities $\left(\mathrm{E}_{\mathrm{i}, \mathrm{c}}\right)$ as well as the effect of the peripherality of the country $\left(\mathrm{G}_{\mathrm{c}}\right)$ on the growth of productivity of each sector, shown in equation (7). Again, the evidence of the relevance of the abundance of capital is robust and agrees with the literature (Feser, 2002, for example), with a positive and significant effect in all sectors except transport equipment (13).

International specialization $\left(\mathrm{E}_{\mathrm{i}, \mathrm{c}}\right)$, is highly significant in almost all industries, and it is usually accompanied by national sectoral specialization $\left(\mathrm{S}_{\mathrm{i}, \mathrm{c}}\right)$; this would mean that, when countries are taken as regions in a supranational context, the fact that an industry concentrates activity in one country may give place also to international location or agglomeration. The exceptions are the paper and printing sector (5), rubber and plastic (8) and electrical and optical equipment (12), where national specialization is significant but international location is not, so that national specialization does not imply the same at the supranational level. Also, international agglomeration is significant for food products, beverages and tobacco (1), other nonmetal and mineral products (9) or coke, refined petroleum products and nuclear fuel (6), but these industries do not need a simultaneous national specialization; and, interestingly, in machinery and other equipment (11), where sectoral concentration tends to be significant when international location is taken into account. 
Peripherality is significant in all industries but coke, refined petroleum products and nuclear fuel (6), rubber and plastic (8), non-metallic minerals (9), metals (10) and transport (13). Regarding the sectors of coke, refined petroleum products and nuclear fuel (6), mineral products (9) and metals (10), the result is logical if we think that these sectors are tied to the existence of natural resources, so international specialization is tied to factor endowments. The transport sector (13) is so important in many countries that governments treat it as a barometer of the economy. For this reason, governments will pull out all the stops to attract new investment or give grants to vulnerable companies. Many developing countries have tried to provide themselves with, for example, a car manufacturing industry (motor vehicles have a higher exportation coefficient than the transport equipment manufacturing sector), with mixed results. Most of the world's car production is concentrated in only six countries: Japan, the USA, Germany, France, Spain and South Korea, followed by five more, the UK, Canada, Italy, Belgium and Brazil. Within those that correspond to our study sample, Spain and Italy are regarded as peripheral. Also, the rubber and plastics sector (8) depends largely on the car manufacturing sector and is closely tied to its progress. Generally, in all these activities the importance of national and/or international specialization is seen both in peripheral and in central countries, and thus geography is not an influence.

In the sectors of food products, beverages and tobacco (1) and machinery and equipment (11) the indication of geography is the opposite of what is expected. The former is a sector with interindustry diseconomies, is negatively influenced by the dynamism of other sectors, and benefits from international but not from national specialization, even before controlling its geographical position, i.e., it is important not at a national level but when compared with other countries. A descriptive analysis of this sector shows us its importance in countries such as Greece, Spain and Italy, countries where culturally the sector related to food may carry enormous weight despite being peripheral, which indicates that they could reasonably be benefited by their geographical position. The second is now remarkable for its externalities of national and international specialization and diversification. It is characterised by a highly qualified workforce and highly technological content where the diffusion of know-how plays a very important part. Competition is also very relevant, which in this case is not diminished by distance, as the sector has high activity in peripheral countries as well 
as in central ones. Perhaps de-localisation, frequent in the internationalisation process of many large companies and most of all in specific high technology sectors, is playing an important part here.

But there is a very relevant result which, in our opinion, is a major contribution of this analysis: some of the national spillovers have weak evidence when the international dimension was not controlled (see column 1 in table 1); they do not show evidence or yield an unexpected result, such as finding that interindustry or diversity externalities might interrupt productivity growth. Indeed, when we dimension both the sample and externalities at the same time, by focusing on an international sample and also introducing international externalities in the estimation, the unexpected results at the national level tend to be consistent with the theory, at the same time that international spillovers have a robust effect on productivity growth. Two changes are worth highlighting: in an international context, national interindustry externalities become more significant and national diversification becomes less relevant.

Indeed, column 2 in table 1 shows that national interindustry externalities (other sectors output growth) are reinforced when international externalities are introduced in the analysis. Now, the dynamism of interindustry links presents robust evidence in activities like refined petroleum and nuclear fuel (6), leather and its products (3), wood and wood products (4), or machinery and other equipment (11), together with national specialization and international location in the last three ones. Apparently, the countries where these industries locate and agglomerate internationally take advantage also from a national specialization and do not need a dynamic and diversified economic structure in order to enjoy interindustry advantages ${ }^{5}$. But, when international agglomeration and peripherality are considered, the productivity growth increases if the industry is concentrated within countries and enjoys interindustry linkages with other dynamic activities, generating a higher value added. Only in food products, beverages and tobacco (1) the growth of other industries seems to be a break to its productivity growth; this evidence is also found in chemicals, chemical products and manmade fibres (7) and basic metals and fabricated metal products (10), but their linkages are not changed by the consideration of international externalities.

\footnotetext{
${ }^{5} \mathrm{We}$ have found a negative correlation between international specialization (E) and dynamism in other industries' growth $\left(\widetilde{q}_{j, c}\right)$.
} 
The other relevant change is that in a wider supranational context, national diversification loses its significance in low technology industries. It could happen that, for a country which agglomerates one activity and is in a central geographical location, the availability of a diversified economic structure and a wide supply of inputs is not important any more; perhaps this country can benefit from the proximity of other international suppliers.

To sum up, we may distinguish three groups of industries according to the effect of externalities on the growth of productivity, and stressing how the effect can change when international spillovers international specialization and geography - are taken into account for an international sample ${ }^{6}$. The first group is that with no effect of international externalities; here we find only rubber and plastic products (8), an industry where only national specialization is significant.

The second group is the biggest one, with mixed results, but where the common and very important feature is that the effect from national externalities is sensitive to the consideration of international spillovers, and these are usually significant. In such a way as to draw attention, national diversification loses significance to a great extent when jointly considered with international spillovers. Moreover, only for three industries, national specialization is no longer significant, but instead, international specialization is - these are food, beverages and tobacco (1), coke, refined petroleum and fuel (6) and other non-metal and mineral products (9). For the rest, national specialization maintains its relevance, together with international specialization, in both sides of Table 1, with the exception of pulp, paper, printing and publishing (5), where international specialization is not significant.

Two industries can be highlighted in this second group because all determinants are significant, and these are wood and its products (4) and machinery and other equipment (11); in both of them the dynamism of other activities reveals significant when international externalities are introduced.

And finally, in the third group, three industries receive a positive effect of international externalities and of national specialization and diversification and, what specifically characterises this group, the effect

\footnotetext{
${ }^{6}$ In all industries but the transport sector (13) capital endowments per worker are important determinants of productivity growth.
} 
from national spillovers does not change if we omit the international dimension; here we find basic metals and metal products (10), electrical and optical equipment (12) and transport equipment (13). These sectors have on average a higher technology level compared to the second group; so, apparently, the low technological industries seem to yield a more evident estimation bias from omitting the international externalities.

Definitively, technological externalities play a role also in the international context, and their omission can skew the effect on productivity growth of national spillovers. Our analysis finds robust and important evidence of specialization, more than diversification, which is in line with most of the literature, for example with De Lucio et al. (2002) and Henderson (2003). Some of these papers maintain that this is evident only in the regional context, where activity finds less friction to localisation; but in this paper we find evidence for the national and international level. We would like to underline again the relevance of considering a geographical dimension of externalities which is accurate to the sample, and so, in an international context both national and international effects should be studied jointly.

Moreover, we also find evidence of interindustry externalities, in line with Midelfart-Knarvik and Steen (2002) and Caballero and Lyons $(1990,1992)$. But we would like to stress that this evidence is sensitive to their joint analysis with international intraindustry externalities when countries are considered as regions and, in some industries, their effect is underestimated when international spillovers are omitted. Also, our results are in line with those obtained by Henriksen et al., (2001), who find interindustry national externalities; mainly in high technology activities. We find this robust evidence also in the more sophisticated industries, such as basic metals and products (10), electrical and optical equipment (12) and transport equipment (13); in less technological industries they are also significant, but only when international agglomeration and peripherality are considered.

\section{Economic integration and externalities as a mechanism of agglomeration}

In our analysis we found evidence about the positive effect on productivity growth of interindustry externalities, technological spillovers like national specialization and diversification in an international 
context, and the relevance of international externalities and the advisability of considering them jointly with the national ones. For this experiment we took the widest homogeneous sample with available information, and this is the majority of EU countries in the studied period. This is a contribution to knowledge of the European case, but we also are conscious that our evidence might have benefited from the fact that the countries in our sample are all developed and geographically close. They also benefit from economic integration that maximizes the mobility of goods and factors and minimizes transaction and transport costs, so that they work as regions in a supranational area, and this is an ideal sample. In this section we ask what would happen with an international but more heterogeneous sample or, alternatively, how economic integration for developed countries can help externalities to work as a mechanism of agglomeration.

There is some literature that relates agglomeration patterns and growth differentials to economic development and geographical position ${ }^{7}$. For instance, Glaeser et al. (1992) and Fujita and Thisse (2002) explain that knowledge spillovers in agglomerations can be a source of sustained regional growth, and different agglomeration patterns imply different growth rates. Also Baldwin and Martin (2003) maintain that concentration exerts a different effect on central or peripheral regions. So there will be developed and central regions which agglomerate knowledge and technology intensive industries, and other peripheral less developed regions with production processes intensive in low tech and low skill labour and, because of the endogenous nature of agglomeration, this pattern fuels growth differentials and vice versa.

Unfortunately, we have information for estimating the effects of externalities only for another small international sample, which lacks endowment information and is a very heterogeneous sample of less developed countries ${ }^{8}$. We re-estimated our empirical model without endowments again for the EU countries and also for the non-EU sample, and sum up the results in table 2 (complete estimations are in the Appendix tables A3 and A4).

\section{TABLE 2 HERE}

\footnotetext{
${ }^{7}$ For a survey of the theoretical and empirical literature about the relationship between knowledge spillovers and differentials in growth see Döring and Schnellenbach (2006).

${ }^{8}$ Argentina, China, Costa Rica, Ecuador, Israel, Morocco, Russian Federation, Singapore and Tunisia.
} 
At first glance, both tables show evidence that externalities are in general less significant for the less developed and non-integrated sample. In this case, most industries benefit from national specialization and, in some cases, together with diversification, such as food products (1), leather and its products (3), pulp, paper, printing and publishing (5), chemicals (7), other non-metal mineral products (9) and basic metals and products (10). In general, for the non-EU countries, only national externalities are significant, which is the main difference with the EU sample, where international specialization and a central geographical location are relevant ${ }^{9}$.

But in this experiment we omit capital per worker because it is not available for non-EU countries, a determinant which was very significant for the EU sample, and is usually more important for less developed countries' specialization. Its omission for the EU sample tends to show a robust pattern for national specialization, a much more significant role of industry diversification, more significance with a habitual underestimation of interindustry linkages, only a little more significance of international agglomeration and much less significance of geographical position. So, assuming that changes follow a similar direction for nonEU countries, by controlling endowments we can expect that national specialization would be the same, geography would be more significant and we would lose evidence about the rest of externalities; perhaps, we might find more evidence about interindustry mechanisms for growth, because geography usually reinforces linkages in the EU sample for less sophisticated activities. The geographic dispersion of the non-European sample may have contributed to this result. Moreover, in the EU sample endowments were positively correlated with diversity, and negatively with international agglomeration and distance. So that, for the nonEU sample, with lower development levels and where capitalization is more important for productivity growth, we can expect a larger bias from endowments omission which means a bigger correction on the effects of externalities when capital per worker is controlled in the analysis: a much lower effect on productivity growth from diversity and a peripheral location besides a much higher benefit from international

\footnotetext{
${ }^{9}$ For the non-EU countries, international specialization is significant only for leather and its products (3) and machinery and other equipment (11), and geography is significant for textiles and their products (2). But this behaviour for these sectors is common for both EU and non-EU subsamples.
} 


\section{Conclusions}

The aim of this study was to analyse the existence of productive externalities in the manufacturing activity of European countries, desegregated by industry and for the period 1995-2002.

The evidence of our analysis suggest the advisability of dimensioning the externalities according to the sample, which means that with an international context and a sample of countries, both national and international externalities should be tested jointly. Moreover, we find evidence of significance not only for national interindustry linkages, but also for national specialization and diversification, something usually tested only for regions within a country; and the evidence also stresses the significance of international specialization and geographical location. Economic integration seems to be relevant so that the externalities act as mechanisms of agglomeration, with countries acting as regions in a supranational area where the mobility of goods and factors is maximized and transaction frictions minimized. 
In our sample of EU countries, our analysis shows that, even with similar factor endowments and geographical proximity, productivity growth is encouraged in those industries with a higher capitalization and, with regard to externalities, national and international specialization are the most significant; also interindustry linkages and, in some cases, national diversification. Omitting international externalities causes a bias in the effect of national ones, because international externalities reinforce the significance of interindustry linkages and weaken the relevance of diversity within a country, at the same time that they reveal that international specialization and central location in a supranational integrated area are significant determinants of productivity growth and growth differentials between country members. Furthermore, lower technological industries are more sensitive to the omission of these international externalities. Thus, it would be beneficial to implement development policies which support sectors whose productivity is liable to benefit from the positive effects of national and international spillovers, which will result in greater economic growth.

In a nutshell, the leitmotiv of the article is that we provide evidence for the underestimation of national externalities if we omit international ones, which makes it necessary to consider an international sample. This underestimation is more intense in low technology industries and in groups of countries which could be classified as integrated.

\section{Appendix. Detailed estimations}

TABLE A1 HERE

TABLE A2 HERE

TABLE A2 HERE

TABLE A4 HERE

References 
Amiti, M., and Cameron, L. (2007) Economic geograpphy and wages, Review of Economics and Statistics, 89, 1, 15-29.

Arellano, M., and Bond, S.R. (1991) Some specification tests for panel data: Monte Carlo evidence and an application to employment equations, Review of Economic Studies, 58, 277-298.

Baldwin, R.E., and Martin, P. (2003) Agglomeration and regional growth, Discussion Paper 3960, CEPR, London.

Blundell, R., and Bond, S.R. (1998) Initial conditions and moment restrictions in dynamic panel data models, Journal of Econometrics, 87,115-143.

Caballero, R., and Lyons, R. (1990) Internal and external economies in European industries, European Economic Review, 34, 805-830.

Caballero, R., and Lyons, R. (1992) External effects in U.S. procyclical productivity, Journal of Monetary Economics, 29, 209-226.

Ciccone, A. (2002) Agglomeration effects in Europe, European Economic Review, 46, 213-227.

Cohen, J.P., and Paul, C.J.M. (2005) Agglomeration economies and industry location decisions: the impacts of spatial and industrial spillovers, Regional Science and Urban Economics, 35, 215-237.

Davis, D.R., and Weinstein, D.E. (2003) Market size, linkages, and productivity. A study of Japanese regions, Discussion Paper, 53, World Institute for Development Economics Research, United Nations University.

De Groot, H.L.F., Poot, J., and Smit, M.J. (2009) Agglomeration Externalities, Innovation and Regional Growth: Theoretical Perspectives and Meta-analysis, in Handbook of Regional Growth and Development Theories, Capello, R. and P. Nijkamp, eds., Cheltenham, U.K. and Northampton, Mass.: Elgar, pp. 25681.

De Lucio, J.J., Herce, J.A., and Goicolea, A. (2002) The effects of externalities on productivity growth in Spanish industry, Regional Science and Urban Economics, 32, 241-258.

Dogan, E. (2001) External scale economies in Turkish manufacturing industries, International Review of Applied Economics, 154, 429-446. 
Döring, T., and Schnellenbach, J. (2006) What do we know about geographical knowledge spillovers and regional growth? A survey of the literature, Regional Studies, 40, 3, 375-395.

Duranton, G., and Puga, D. (2004) Micro-foundations of urban agglomeration economies, in Handbook of Regional and Urban Economics, Cities and Geography, (Eds.) J.V. Henderson and Thisse, J.F., 4, Amsterdam: North-Holland, pp. 2063-2117.

Feser, E.J. (2001) A flexible test for agglomeration economies in two US manufacturing industries, Regional Science and Urban Economics, 31, 1-19.

Feser, E.J. (2002) Tracing the sources of local external economies, Urban Studies, 3913, 2485-2506.

Fujita, M., and Thisse, J.F. (2002) Does geographical agglomeration foster economic growth? And who gains and loses from it? Discussion Paper 3135, CEPR, London.

Glaeser, E.L., Kallal, H.D., Sheinkman, J.A., and Shleifer, A. (1992) Growth in cities, Journal of Political Economy, 100, pp. 1126-1152.

Graham, D.J. (2000) Spatial variation in labour productivity in British manufacturing, International Review of Applied Economics, 143, 323-341.

Hausman, J.A. (1976) Specification tests in econometrics, Econometrica, 46, 1251-1271.

Henderson, J.V. (1986) Efficiency of resource usage and city size, Journal of Urban Economics, 19, 47-70.

Henderson, J.V. (1997) Externalities and industrial development, Journal of Urban Economics, 42, 449-470.

Henderson, J.V. (2003) Marshall's scale economies, Journal of Urban Economics, 53, 1-28.

Henriksen, E., Midelfart-Knarvik, K.H., and Steen, F. (2001) Economies of scale in European manufacturing revisited, Centre for Economic Policy Research, Discussion Paper, vol. 2896.

Hoover, E.M. (1937) Location Theory and The Shoe and Leather Industries. Cambridge, MA: Harvard University Press.

Lall, S.V., Shalizi, Z., and Deichmann, U. (2004) Agglomeration economies and productivity in Indian industry, Journal of Development Economics, 73, 643-673. 
Marshall, A. (1923) Industry and Trade. London: McMillan.

Martin, P., and Ottaviano, G. (1996) Growth and agglomeration, Centre for Economic Policy Research, Discussion paper, 1529.

Midelfart-Knarvik, K.H., and Steen, F. (2002) 'Vertical industry linkages: sources of productivity gains and cumulative causation?' Review of Industrial Organization, Vol. 21, pp. 3-20.

Moomaw, R.L. (1988) Agglomeration economies: Are they exaggerate by industrial aggregation? Regional Science and Urban Economics, 28, 199-211.

Nakamura, R. (1985) Agglomeration economies in urban manufacturing industries, a case of Japanese cities, Journal of Urban Economics, 17, 108-124.

Partridge, M.D., and Rickman, D.S. (1999) Static and dynamic externalities, industry composition, and state labour productivity: a panel study of states, Southern Economic Journal, 662, 319-335.

Puga, D. (2009) The magnitude and causes of agglomeration economies, IMDEA working paper 2009-09.

Rosenthal, S.S., and Strange, W.C. (2004) Evidence on the nature and sources of agglomeration economies, In Handbook of Regional and Urban Economics, Cities and Geography, (Eds.) Henderson, J.V., and Thisse, J.F., 4. Amsterdam: North-Holland.

Scitovsky, T. (1954) Two concepts of external economies, Journal of Political Economy, 63, 143-151.

Serrano, G. (2000) Economías externas y productividad del trabajo, Revista de Economía Aplicada, 24, $105-$ 135.

Smith, P.J. (1999) Do knowledge spillovers contribute to US states output and growth? Journal of Urban Economics, 45, 331-353.

Weber, A. (1929) Theory of the Location of Industries. Chicago: University of Chicago Press.

Windmeijer, F. (2005) A finite sample correction for the variance of linear two-step GMM estimators, Journal of Econometrics, 126, 1, 25-51. 


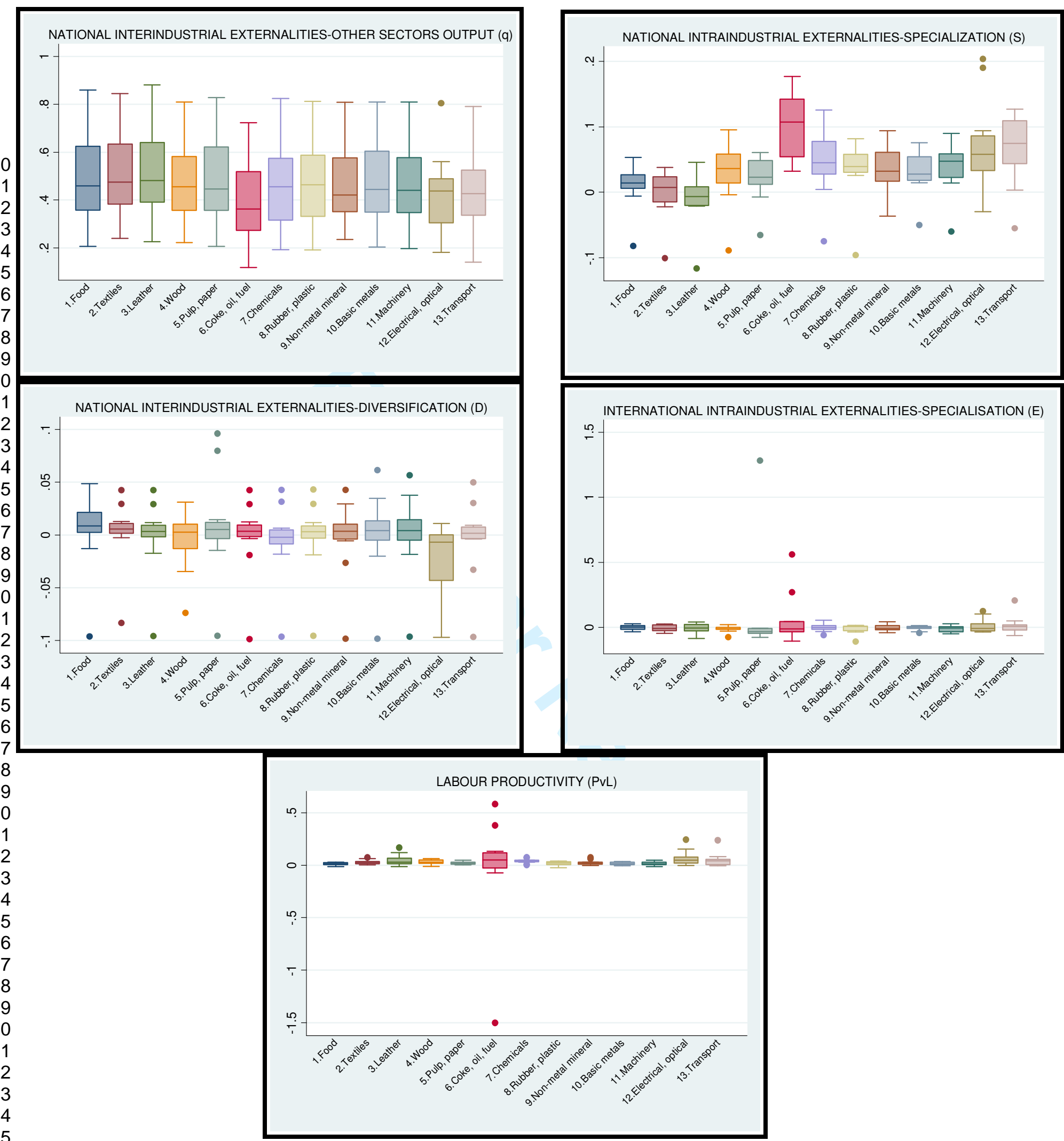

Fig. 1: Externalities and labour productivity by industry. Growth rates. 
Table 1. Summary of significant variables and coefficients.

Dependent variable: labour productivity growth rate (1995-2002)

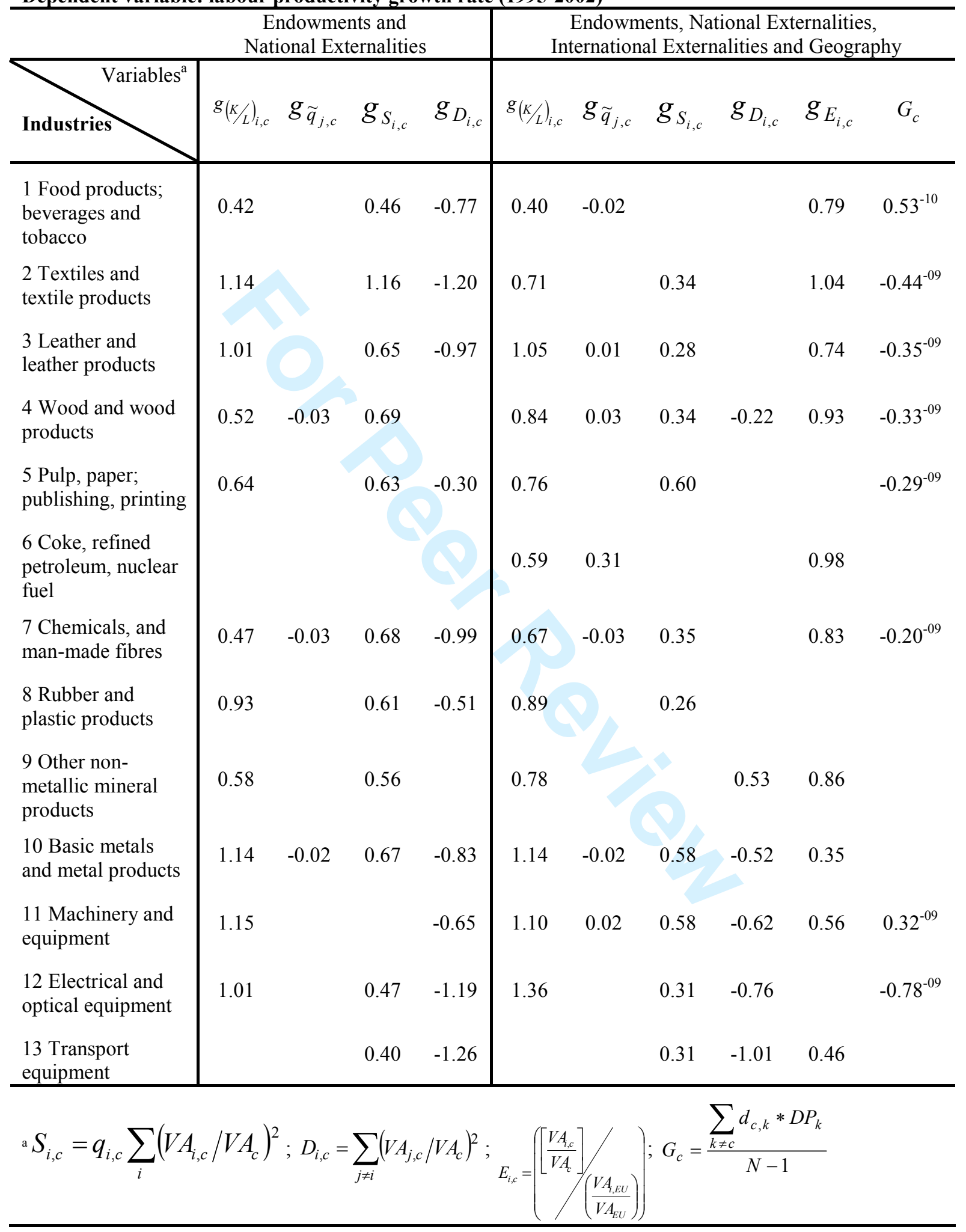


Table 2. Summary of significant variables and coefficients. Dependent variable: labour productivity growth rate (1995-2002)

Endowments, National Externalities, International Externalities and Geography

\begin{tabular}{|c|c|c|c|c|c|c|c|c|c|c|}
\hline \multicolumn{6}{|c|}{ EU } & \multicolumn{5}{|c|}{ Non-EU ${ }^{b}$} \\
\hline Industries & $g_{\widetilde{q}_{j, c}}$ & $g_{S_{i, c}}$ & $g_{D_{i, c}}$ & $g_{E_{i, c}}$ & $G_{c}$ & $g_{\widetilde{q}_{j, c}}$ & $g_{S_{i, c}}$ & $g_{D_{i, c}}$ & $g_{E_{i, c}}$ & $G_{c}$ \\
\hline $\begin{array}{l}1 \text { Food products; } \\
\text { beverages, tobacco }\end{array}$ & & 0.64 & -0.67 & & $3.29^{-11}$ & 0.04 & 0.41 & -0.25 & & \\
\hline $\begin{array}{l}2 \text { Textiles and } \\
\text { textile products }\end{array}$ & & & -0.54 & 0.60 & $-0.32^{-09}$ & & & & & $-8.80^{-17}$ \\
\hline $\begin{array}{l}3 \text { Leather and } \\
\text { leather products }\end{array}$ & & -0.59 & & 0.59 & & & 1.27 & -0.99 & 0.03 & \\
\hline $\begin{array}{l}4 \text { Wood and wood } \\
\text { products }\end{array}$ & 0.04 & & -0.15 & 0.52 & $3.18^{-11}$ & 0.17 & & & & \\
\hline $\begin{array}{l}5 \text { Pulp, paper; } \\
\text { publishing, printing }\end{array}$ & & 0.48 & -0.56 & & & & 0.61 & -0.78 & & \\
\hline $\begin{array}{l}6 \text { Coke, refined } \\
\text { petroleum, nuclear } \\
\text { fuel }\end{array}$ & & -0.22 & -0.73 & 1.17 & & & 0.82 & & & \\
\hline $\begin{array}{l}7 \text { Chemicals, and } \\
\text { man-made fibres }\end{array}$ & -0.02 & 0.49 & -0.59 & 0.35 & $0.30^{-10}$ & & 1.57 & -2.56 & & \\
\hline $\begin{array}{l}8 \text { Rubber and } \\
\text { plastic products }\end{array}$ & & 0.44 & -0.94 & 0.47 & & 0.05 & 0.24 & & & \\
\hline $\begin{array}{l}9 \text { Other non- } \\
\text { metallic mineral } \\
\text { products }\end{array}$ & & & -0.40 & 0.31 & & 0.04 & 0.32 & -0.51 & & \\
\hline $\begin{array}{l}10 \text { Basic metals } \\
\text { and metal products }\end{array}$ & & 0.52 & -0.60 & 0.19 & & & 0.91 & -0.45 & & \\
\hline $\begin{array}{l}11 \text { Machinery and } \\
\text { equipment }\end{array}$ & & 0.53 & -0.80 & 0.30 & & 0.03 & & & 0.32 & \\
\hline $\begin{array}{l}12 \text { Electrical and } \\
\text { optical equipment }\end{array}$ & & 0.41 & -0.61 & 0.56 & & & 0.76 & & & \\
\hline $\begin{array}{l}13 \text { Transport } \\
\text { equipment }\end{array}$ & -0.03 & 0.38 & -1.04 & 0.59 & & & & & & \\
\hline${ }^{\mathrm{a}} S_{i, c}=q_{i, c} \sum_{i}(V A$ & $\left(V A_{c}\right)$ & $D_{i, c}$ & $\sum_{\neq i}\left(V A_{j, c}\right.$ & $\left(A_{c}\right)^{2}$ & & & $=\frac{\sum_{k \neq c}}{c}$ & $\begin{array}{l}d_{c, k} * D \\
N-1\end{array}$ & & \\
\hline
\end{tabular}




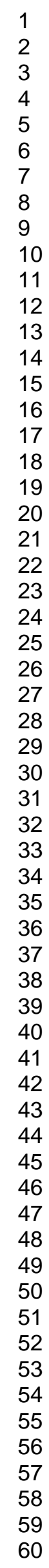

25

26

27

29

30

33

34

35

36

37

38

41

42

43

45

46

47

48

50

51

52

53

54

55

57

58

59

60 


\section{Appendix. Detailed estimations}

Table A1: Endowments and National Externalities

\begin{tabular}{|c|c|c|c|c|c|c|}
\hline & $g(K / L)_{i, c}$ & $g_{\widetilde{q}_{j, c}}$ & $g_{S_{i, c}}$ & $g_{D_{i, c}}$ & & \\
\hline $\begin{array}{l}1 \text { Food products; beverages and } \\
\text { tobacco }\end{array}$ & $\begin{array}{l}0.42 * \\
(1.88)\end{array}$ & $\begin{array}{l}-0.0013 \\
(-0.13)\end{array}$ & $\begin{array}{l}0.46^{*} \\
(3.13)\end{array}$ & $\begin{array}{l}-0.77 * \\
(-3.43)\end{array}$ & $\begin{array}{l}R^{2} A j=0.28 \\
\text { Nobs }=43\end{array}$ & $\begin{array}{l}\mathrm{F}(6,32)=1.66 \\
\mathrm{CHISQ}(2)=3.05\end{array}$ \\
\hline 2 Textiles and textile products & $\begin{array}{l}1.14^{*} \\
(4.41)\end{array}$ & $\begin{array}{l}-0.03 \\
(-1.59)\end{array}$ & $\begin{array}{l}1.16^{*} \\
(4.22)\end{array}$ & $\begin{array}{l}-1.20 * \\
(-3.28)\end{array}$ & $\begin{array}{l}R^{2} A j=0.52 \\
\text { Nobs }=32\end{array}$ & $\begin{array}{l}\mathrm{F}(4,23)=3.85 \\
\mathrm{CHISQ}(3)=6.67\end{array}$ \\
\hline 3 Leather and leather products & $\begin{array}{c}1.01 * \\
(16.11)\end{array}$ & $\begin{array}{c}-0.01 \\
(-0.84)\end{array}$ & $\begin{array}{l}0.65^{*} \\
(4.49)\end{array}$ & $\begin{array}{l}-0.97 * \\
(-2.40)\end{array}$ & $\begin{array}{l}R^{2} \mathrm{Aj}=0.81 \\
\text { Nobs }=32\end{array}$ & $\begin{array}{l}\mathrm{F}(4,23)=6.57 \\
\mathrm{CHISQ}(1)=0.0022\end{array}$ \\
\hline 4 Wood and wood products & $\begin{array}{l}0.52 * \\
(2.11)\end{array}$ & $\begin{array}{l}-0.03 * * \\
(-1.95)\end{array}$ & $\begin{array}{l}0.69 * \\
(5.07)\end{array}$ & $\begin{array}{c}0.13 \\
(0.66)\end{array}$ & $\begin{array}{l}R^{2} \mathrm{Aj}=0.32 \\
\text { Nobs }=39\end{array}$ & $\begin{array}{l}\mathrm{F}(5,29)=0.48 \\
\mathrm{CHISQ}(3)=0.74\end{array}$ \\
\hline $\begin{array}{l}5 \text { Pulp, paper and paper } \\
\text { products; publishing and } \\
\text { printing }\end{array}$ & $\begin{array}{l}0.64 * \\
(4.78)\end{array}$ & $\begin{array}{l}-0.02 \\
(-1.52)\end{array}$ & $\begin{array}{l}0.63 * \\
(5.33)\end{array}$ & $\begin{array}{l}-0.30 * \\
(-2.25)\end{array}$ & $\begin{array}{l}R^{2} A j=0.44 \\
\text { Nobs }=43\end{array}$ & $\begin{array}{l}\mathrm{F}(6,32)=2.01 \\
\mathrm{CHISQ}(2)=31.28\end{array}$ \\
\hline $\begin{array}{l}6 \text { Coke, refined petroleum } \\
\text { products and nuclear fuel }\end{array}$ & $\begin{array}{c}0.45 \\
(0.40)\end{array}$ & $\begin{array}{c}0.01 \\
(0.05)\end{array}$ & $\begin{array}{c}0.06 \\
(0.14)\end{array}$ & $\begin{array}{l}-5.14 \\
(-0.97)\end{array}$ & $\begin{array}{l}R^{2} A j=-0.08 \\
\text { Nobs }=43\end{array}$ & $\begin{array}{l}\mathrm{F}(6,32)=0.80 \\
\mathrm{CHISQ}(1)=0.75\end{array}$ \\
\hline $\begin{array}{l}7 \text { Chemicals, chemical products } \\
\text { and man-made fibres }\end{array}$ & $\begin{array}{l}0.47 * \\
(2.59)\end{array}$ & $\begin{array}{l}-0.03 * \\
(-3.30)\end{array}$ & $\begin{array}{l}0.68^{*} \\
(7.58)\end{array}$ & $\begin{array}{l}-0.99 * \\
(-4.43)\end{array}$ & $\begin{array}{l}R^{2} \mathrm{Aj}=0.66 \\
\text { Nobs }=39\end{array}$ & $\begin{array}{l}\mathrm{F}(5,29)=2.48 \\
\mathrm{CHISQ}(2)=1.59\end{array}$ \\
\hline 8 Rubber and plastic products & $\begin{array}{l}0.93 * \\
(5.08)\end{array}$ & $\begin{array}{c}-0.01 \\
(-0.97)\end{array}$ & $\begin{array}{l}0.61 * \\
(4.99)\end{array}$ & $\begin{array}{l}-0.51 * * \\
(-1.71)\end{array}$ & $\begin{array}{l}R^{2} \mathrm{Aj}=0.39 \\
\text { Nobs }=43\end{array}$ & $\begin{array}{l}\mathrm{F}(5,29)=0.84 \\
\mathrm{CHISQ}(2)=0.021\end{array}$ \\
\hline $\begin{array}{l}9 \text { Other non-metallic mineral } \\
\text { products }\end{array}$ & $\begin{array}{l}0.58 * \\
(4.54)\end{array}$ & $\begin{array}{l}-0.01 \\
(-1.39)\end{array}$ & $\begin{array}{l}0.56^{*} \\
(4.29)\end{array}$ & $\begin{array}{c}-0.41 \\
(-1.36)\end{array}$ & $\begin{array}{l}R^{2} \mathrm{Aj}=0.32 \\
\text { Nobs }=43\end{array}$ & $\begin{array}{l}\mathrm{F}(6,32)=0.72 \\
\mathrm{CHISQ}(2)=0.60\end{array}$ \\
\hline $\begin{array}{l}10 \text { Basic metals and fabricated } \\
\text { metal products }\end{array}$ & $\begin{array}{l}1.14^{*} \\
(7.53)\end{array}$ & $\begin{array}{l}-0.02 * \\
(-3.20)\end{array}$ & $\begin{array}{l}0.67 * \\
(8.15)\end{array}$ & $\begin{array}{l}-0.83^{*} \\
(-5.14)\end{array}$ & $\begin{array}{l}R^{2} \mathrm{Aj}=0.81 \\
\text { Nobs }=32\end{array}$ & $\begin{array}{l}\mathrm{F}(4,23)=14.28 \\
\mathrm{CHISQ}(1)=7.78\end{array}$ \\
\hline 11 Machinery and equipment & $\begin{array}{l}1.15^{*} \\
(1.92)\end{array}$ & $\begin{array}{c}0.01 \\
(0.14)\end{array}$ & $\begin{array}{l}0.74 \\
(1.17)\end{array}$ & $\begin{array}{l}-0.65^{*} \\
(-4.42)\end{array}$ & $\begin{array}{l}\text { Prob }>\text { CHISC } \\
\text { Nobs }=43\end{array}$ & $\begin{array}{r}\mathrm{Q}=0.26 \mathrm{~F}(4,7)=62.94 \\
\mathrm{p}-\mathrm{H}: \mathrm{CHISQ}(1)=1.29\end{array}$ \\
\hline $\begin{array}{l}12 \text { Electrical and optical } \\
\text { equipment }\end{array}$ & $\begin{array}{l}1.01 * \\
(4.24)\end{array}$ & $\begin{array}{l}0.001 \\
(0.04)\end{array}$ & $\begin{array}{l}0.47 * \\
(3.66)\end{array}$ & $\begin{array}{l}-1.19 * \\
(-3.08)\end{array}$ & $\begin{array}{l}R^{2} A j=0.77 \\
\text { Nobs }=28\end{array}$ & $\begin{array}{l}\mathrm{F}(6,32)=3.41 \\
\mathrm{CHISQ}(3)=7.98\end{array}$ \\
\hline 13 Transport equipment & $\begin{array}{c}0.14 \\
(0.58)\end{array}$ & $\begin{array}{l}-0.003 \\
(-0.19)\end{array}$ & $\begin{array}{l}0.40^{*} \\
(2.50)\end{array}$ & $\begin{array}{l}-1.26 * \\
(-3.40)\end{array}$ & $\begin{array}{l}\mathrm{R}^{2} \mathrm{Aj}=0.25 \\
\text { Nobs }=43\end{array}$ & $\begin{array}{l}\mathrm{F}(6,32)=1.56 \\
\mathrm{CHISQ}(3)=3.21\end{array}$ \\
\hline
\end{tabular}

Note. t-statistics in parentheses. $* 5 \%$ significance level except $* *$ at $10 \%$. CHISQ(n) Hausman test statistic. F () Statistic for homogeneity of individual effects hypothesis. p-H Hansen test of overidentifying restrictions, for those sectors which have presented endogeneity. Prob>CHISQ Hausman endogeneity statistic. 
Table A2: Endowments, National Externalities, International Externalities and Geography

\begin{tabular}{|c|c|c|c|c|c|c|c|c|}
\hline & $\left.g_{(K / L}\right)_{i, c}$ & $g_{\widetilde{q}_{j, c}}$ & $g_{S_{i, c}}$ & $g_{D_{i, c}}$ & $g_{E_{i, c}}$ & $G_{c}$ & & \\
\hline $\begin{array}{l}1 \text { Food products; } \\
\text { beverages and } \\
\text { tobacco }\end{array}$ & $\begin{array}{l}0.40^{*} \\
(2.35)\end{array}$ & $\begin{array}{l}-0.02^{*} \\
(-2.12)\end{array}$ & $\begin{array}{c}0.05 \\
(0.40)\end{array}$ & $\begin{array}{c}0.32 \\
(1.13)\end{array}$ & $\begin{array}{l}0.79 * \\
(5.05)\end{array}$ & $\begin{array}{l}0.53^{-10_{*}} \\
(2.50)\end{array}$ & $\begin{array}{l}R^{2} A j=0.58 \\
\text { Nobs }=43\end{array}$ & $\begin{array}{l}\mathrm{F}(6,30)=1.64 \\
\mathrm{CHISQ}(2)=4.20\end{array}$ \\
\hline $\begin{array}{l}2 \text { Textiles and } \\
\text { textile products }\end{array}$ & $\begin{array}{l}0.71 * \\
(5.81)\end{array}$ & $\begin{array}{l}-0.001 \\
(-0.13)\end{array}$ & $\begin{array}{l}0.34 * \\
(2.21)\end{array}$ & $\begin{array}{c}0.26 \\
(0.91)\end{array}$ & $\begin{array}{l}1.04 * \\
(8.94)\end{array}$ & $\begin{array}{c}-0.44^{-09 *} * \\
(-3.67)\end{array}$ & $\begin{array}{l}R^{2} A j=0.87 \\
\text { Nobs }=32\end{array}$ & $\begin{array}{l}\mathrm{F}(4,21)=15.10 \\
\mathrm{CHISQ}(1)=2.74\end{array}$ \\
\hline $\begin{array}{l}3 \text { Leather and } \\
\text { leather products }\end{array}$ & $\begin{array}{c}1.05^{*} \\
(32.89)\end{array}$ & $\begin{array}{c}0.01^{* *} \\
(1.78)\end{array}$ & $\begin{array}{l}0.28^{*} \\
(4.83)\end{array}$ & $\begin{array}{c}-0.07 \\
(-0.37)\end{array}$ & $\begin{array}{c}0.74^{*} \\
(10.18)\end{array}$ & $\begin{array}{c}-0.35^{-09 *} \\
(-3.11)\end{array}$ & $\begin{array}{l}R^{2} A j=0.97 \\
\text { Nobs }=32\end{array}$ & $\begin{array}{l}\mathrm{F}(4,21)=15.65 \\
\mathrm{CHISQ}(1)=15.28\end{array}$ \\
\hline $\begin{array}{l}4 \text { Wood and wood } \\
\text { products }\end{array}$ & $\begin{array}{l}0.84^{*} \\
(4.28)\end{array}$ & $\begin{array}{l}0.03 * \\
(2.84)\end{array}$ & $\begin{array}{l}0.34 * \\
(2.59)\end{array}$ & $\begin{array}{l}-0.22^{*} \\
(-2.14)\end{array}$ & $\begin{array}{r}0.93 * \\
(5.35)\end{array}$ & $\begin{array}{l}-0.33^{-09 *} * \\
(-2.20)\end{array}$ & $\begin{array}{l}R^{2} A j=0.75 \\
\text { Nobs }=39\end{array}$ & $\begin{array}{l}\mathrm{F}(5,27)=3.81 \\
\mathrm{CHISQ}(3)=6.23\end{array}$ \\
\hline $\begin{array}{l}5 \text { Pulp, paper; } \\
\text { publishing, printing }\end{array}$ & $\begin{array}{l}0.76^{*} \\
(7.80)\end{array}$ & $\begin{array}{l}-0.001 \\
(-0.03)\end{array}$ & $\begin{array}{l}0.60^{*} \\
(3.93)\end{array}$ & $\begin{array}{c}-0.11 \\
(-0.98)\end{array}$ & $\begin{array}{c}0.21 \\
(1.26)\end{array}$ & $\begin{array}{c}-0.29^{-09 * *} \\
(-1.85)\end{array}$ & $\begin{array}{l}R^{2} A j=0.57 \\
\text { Nobs }=43\end{array}$ & $\begin{array}{l}\mathrm{F}(6,30)=2.77 \\
\mathrm{CHISQ}(2)=23.04\end{array}$ \\
\hline $\begin{array}{l}6 \text { Coke, refined } \\
\text { petroleum, nuclear } \\
\text { fuel }\end{array}$ & $\begin{array}{l}0.59 * \\
(2.37)\end{array}$ & $\begin{array}{l}0.31^{*} \\
(5.81)\end{array}$ & $\begin{array}{l}-0.15 \\
(-1.09)\end{array}$ & $\begin{array}{c}-3.49 \\
(-1.37)\end{array}$ & $\begin{array}{c}0.98^{*} \\
(11.02)\end{array}$ & $\begin{array}{l}-0.57^{-5} \\
(-0.81)\end{array}$ & $\begin{array}{l}\text { Prob }>\text { CHISQ } \\
\text { Nobs }=43\end{array}$ & $\begin{array}{l}=0.81 \quad F(6,7)=137.9 \\
p-H: C H I S Q(2)=0.41\end{array}$ \\
\hline $\begin{array}{l}7 \text { Chemical products } \\
\text { and man-made } \\
\text { fibres }\end{array}$ & $\begin{array}{l}0.67 * \\
(4.47)\end{array}$ & $\begin{array}{l}-0.03^{*} \\
(-2.95)\end{array}$ & $\begin{array}{l}0.35^{*} \\
(3.60)\end{array}$ & $\begin{array}{l}0.02 \\
(0.08)\end{array}$ & $\begin{array}{l}0.83^{*} \\
(6.14)\end{array}$ & $\begin{array}{c}-0.20^{-09 * *} \\
(-1.66)\end{array}$ & $\begin{array}{l}R^{2} A j=0.87 \\
\text { Nobs }=39\end{array}$ & $\begin{array}{l}\mathrm{F}(5,27)=4.74 \\
\mathrm{CHISQ}(3)=6.81\end{array}$ \\
\hline $\begin{array}{l}8 \text { Rubber and plastic } \\
\text { products }\end{array}$ & $\begin{array}{l}0.89^{*} \\
(3.69)\end{array}$ & $\begin{array}{c}-0.01 \\
(-0.28)\end{array}$ & $\begin{array}{l}0.26^{* *} \\
(1.65)\end{array}$ & $\begin{array}{c}0.30 \\
(0.62)\end{array}$ & $\begin{array}{c}0.69 \\
(0.54)\end{array}$ & $\begin{array}{l}-0.11^{-5} \\
(-0.40)\end{array}$ & $\begin{array}{l}\text { Prob }>\text { CHIS } \\
\text { Nobs }=39\end{array}$ & $\begin{array}{c}\mathrm{Q}=1.00 \mathrm{~F}(6,6)=232 \\
\mathrm{CHISQ}(2)=0.00\end{array}$ \\
\hline $\begin{array}{l}9 \text { Other non-metal } \\
\text { mineral products }\end{array}$ & $\begin{array}{l}0.78^{*} \\
(6.74)\end{array}$ & $\begin{array}{c}0.01 \\
(1.45)\end{array}$ & $\begin{array}{c}0.18 \\
(1.36)\end{array}$ & $\begin{array}{l}0.53 * * \\
(1.73)\end{array}$ & $\begin{array}{l}0.86^{*} \\
(5.41)\end{array}$ & $\begin{array}{l}0.14^{-10} \\
(0.56)\end{array}$ & $\begin{array}{l}\mathrm{R}^{2} \mathrm{Aj}=0.57 \\
\text { Nobs }=43 \\
\mathrm{H}: \mathrm{CHISQ}(2\end{array}$ & $\begin{array}{l}\mathrm{F}(6,30)=1.81 \\
\mathrm{p}- \\
\mathrm{2})=0.84\end{array}$ \\
\hline $\begin{array}{l}10 \text { Basic metals and } \\
\text { metal products }\end{array}$ & $\begin{array}{l}1.14^{*} \\
(7.05)\end{array}$ & $\begin{array}{l}-0.02 * \\
(-3.03)\end{array}$ & $\begin{array}{l}0.58^{*} \\
(5.23)\end{array}$ & $\begin{array}{l}-0.52 * * \\
(-1.88)\end{array}$ & $\begin{array}{r}0.35^{* *} \\
(1.68)\end{array}$ & $\begin{array}{l}-0.48^{-10} \\
(-0.58)\end{array}$ & $\begin{array}{l}R^{2} A j=0.82 \\
\text { Nobs }=32\end{array}$ & $\begin{array}{l}\mathrm{F}(4,21)=12.91 \\
\mathrm{CHISQ}(2)=5.64\end{array}$ \\
\hline $\begin{array}{l}11 \text { Machinery and } \\
\text { equipment }\end{array}$ & $\begin{array}{l}1.10^{*} \\
(4.10)\end{array}$ & $\begin{array}{l}0.02 * * \\
(1.69)\end{array}$ & $\begin{array}{l}0.58^{*} \\
(5.12)\end{array}$ & $\begin{array}{l}-0.62^{*} \\
(-2.59)\end{array}$ & $\begin{array}{l}0.56^{*} \\
(3.70)\end{array}$ & $\begin{array}{c}0.32^{-09} * \\
(2.10)\end{array}$ & $\begin{array}{l}R^{2} A j=0.71 \\
\text { Nobs }=39\end{array}$ & $\begin{array}{l}\mathrm{F}(6,30)=3.60 \\
\mathrm{CHISQ}(2)=45.19\end{array}$ \\
\hline $\begin{array}{l}12 \text { Electrical and } \\
\text { optical equipment }\end{array}$ & $\begin{array}{l}1.36^{*} \\
(4.86)\end{array}$ & $\begin{array}{c}0.03 \\
(1.61)\end{array}$ & $\begin{array}{l}0.31^{*} \\
(2.56)\end{array}$ & $\begin{array}{l}-0.76^{*} \\
(-2.03)\end{array}$ & $\begin{array}{c}0.38 \\
(1.63)\end{array}$ & $\begin{array}{c}-0.78^{-09 *} \\
(-2.62)\end{array}$ & $\begin{array}{l}R^{2} A j=0.82 \\
\text { Nobs }=43\end{array}$ & $\begin{array}{l}\mathrm{F}(6,30)=2.94 \\
\mathrm{CHISQ}(3)=27.69\end{array}$ \\
\hline $\begin{array}{l}13 \text { Transport } \\
\text { equipment }\end{array}$ & $\begin{array}{c}0.29 \\
(1.28)\end{array}$ & $\begin{array}{l}-0.02 \\
(-1.22)\end{array}$ & $\begin{array}{l}0.31 * \\
(2.08)\end{array}$ & $\begin{array}{l}-1.01^{*} \\
(-2.88)\end{array}$ & $\begin{array}{l}0.46^{*} \\
(3.27)\end{array}$ & $\begin{array}{l}0.45^{-10} \\
(1.06)\end{array}$ & $\begin{array}{l}\mathrm{R}^{2} \mathrm{Aj}=0.39 \\
\text { Nobs }=43\end{array}$ & $\begin{array}{l}\mathrm{F}(6,30)=1.56 \\
\mathrm{CHISQ}(3)=1.25\end{array}$ \\
\hline
\end{tabular}

Note. To see Table A1. 
Table A3: EU: National Externalities, International Externalities and Geography

\begin{tabular}{|c|c|c|c|c|c|c|}
\hline & $g_{\widetilde{q}_{j, c}}$ & $g_{S_{i, c}}$ & $g_{D_{i, c}}$ & $g_{E_{i, c}}$ & $G_{c}$ & \\
\hline $\begin{array}{l}1 \text { Food products; } \\
\text { beverage and tobacco }\end{array}$ & $\begin{array}{c}-0.01 \\
(-1.22)\end{array}$ & $\begin{array}{c}0.64 * * \\
(1.65)\end{array}$ & $\begin{array}{l}-0.67 * \\
(-2.38)\end{array}$ & $\begin{array}{c}0.12 \\
(0.45)\end{array}$ & $\begin{array}{l}3.29^{-11 *} \\
(3.61)\end{array}$ & $\begin{array}{l}\text { Prob }>\text { CHISQ }=0.08 \text { F }(5,12)=3.97 \\
\text { Nobs }=76 \quad \text { p-H:CHISQ }(2)=5.06\end{array}$ \\
\hline $\begin{array}{l}2 \text { Textiles and textile } \\
\text { products }\end{array}$ & $\begin{array}{l}0.005 \\
(0.55)\end{array}$ & $\begin{array}{c}0.12 \\
(0.82)\end{array}$ & $\begin{array}{l}-0.54 * \\
(-4.16)\end{array}$ & $\begin{array}{l}0.60^{*} \\
(4.02)\end{array}$ & $\begin{array}{l}-0.32^{-09} * \\
(-2.46)\end{array}$ & $\begin{array}{ll}R^{2} A j=0.48 & F(11,59)=2.58 \\
\text { Nobs }=76 & \text { CHISQ }(3)=6.28\end{array}$ \\
\hline $\begin{array}{l}3 \text { Leather and leather } \\
\text { products }\end{array}$ & $\begin{array}{c}-0.01 \\
(-0.49)\end{array}$ & $\begin{array}{l}-0.59 * \\
(-2.26)\end{array}$ & $\begin{array}{c}0.20 \\
(0.55)\end{array}$ & $\begin{array}{l}0.59^{*} \\
(2.65)\end{array}$ & $\begin{array}{l}-0.24^{-10} \\
(-0.26)\end{array}$ & $\begin{array}{ll}\mathrm{R}^{2} \mathrm{Aj}=0.06 & \mathrm{~F}(11,59)=0.51 \\
\text { Nobs }=76 & \mathrm{CHISQ}(2)=0.8^{-01}\end{array}$ \\
\hline $\begin{array}{l}4 \text { Wood and wood } \\
\text { products }\end{array}$ & $\begin{array}{l}0.04 * \\
(4.24)\end{array}$ & $\begin{array}{l}-0.08 \\
(-0.47)\end{array}$ & $\begin{array}{l}-0.15 * * \\
(-1.82)\end{array}$ & $\begin{array}{l}0.52 * * \\
(1.88)\end{array}$ & $\begin{array}{l}3.18^{-11 *} \\
(3.98)\end{array}$ & $\begin{array}{l}\text { Prob }>\text { CHISQ }=0.19 \mathrm{~F}(5,12)=11.1 \\
\text { Nobs }=74 \quad \text { p-H:CHISQ }(4)=6.14\end{array}$ \\
\hline $\begin{array}{l}5 \text { Pulp, paper; } \\
\text { publishing, printing }\end{array}$ & $\begin{array}{l}0.14^{-02} \\
(0.09)\end{array}$ & $\begin{array}{l}0.48^{*} \\
(3.99)\end{array}$ & $\begin{array}{l}-0.56^{*} \\
(-5.41)\end{array}$ & $\begin{array}{c}0.09 \\
(0.96)\end{array}$ & $\begin{array}{l}0.28^{-10} \\
(1.18)\end{array}$ & $\begin{array}{ll}\mathrm{R}^{2} \mathrm{Aj}=0.27 & \mathrm{~F}(11,59)=2.13 \\
\text { Nobs }=76 & \mathrm{CHISQ}(3)=4.41\end{array}$ \\
\hline $\begin{array}{l}6 \text { Coke, refined petrol, } \\
\text { nuclear fuel }\end{array}$ & $\begin{array}{l}0.33^{*} \\
(3.84)\end{array}$ & $\begin{array}{l}-0.22 * \\
(-3.27)\end{array}$ & $\begin{array}{l}-0.73 * \\
(-2.40)\end{array}$ & $\begin{array}{c}1.17^{*} \\
(29.63)\end{array}$ & $\begin{array}{l}-8.33^{-11} \\
(-1.48)\end{array}$ & $\begin{array}{l}\text { Prob }>\text { CHISQ }=0.5 \mathrm{~F}(5,11)=424.1 \\
\text { Nobs }=72 \quad \text { p-H:CHISQ }(4)=3.35\end{array}$ \\
\hline $\begin{array}{l}7 \text { Chemical products } \\
\text { and man-made fibres }\end{array}$ & $\begin{array}{l}-0.02 * \\
(-2.39)\end{array}$ & $\begin{array}{l}0.49^{*} \\
(5.00)\end{array}$ & $\begin{array}{l}-0.59 * \\
(-5.97)\end{array}$ & $\begin{array}{l}0.35^{*} \\
(3.14)\end{array}$ & $\begin{array}{l}0.30^{-10 * *} \\
(1.65)\end{array}$ & $\begin{array}{lc}\mathrm{R}^{2} \mathrm{Aj}=0.53 & \mathrm{~F}(11,59)=1.17 \\
\text { Nobs }=76 & \mathrm{CHISQ}(3)=1.20\end{array}$ \\
\hline $\begin{array}{l}8 \text { Rubber and plastic } \\
\text { products }\end{array}$ & $\begin{array}{c}-0.02 \\
(-1.20)\end{array}$ & $\begin{array}{c}0.44 * * \\
(1.92)\end{array}$ & $\begin{array}{l}-0.94^{*} \\
(-2.45)\end{array}$ & $\begin{array}{l}0.47^{*} \\
(3.06)\end{array}$ & $\begin{array}{l}3.05^{-12} \\
(0.14)\end{array}$ & $\begin{array}{l}\text { Prob }>\text { CHISQ }=0.5 \mathrm{~F}(5,12)=13.39 \\
\text { Nobs }=76 \quad \text { p-H:CHISQ }(4)=3.40\end{array}$ \\
\hline $\begin{array}{l}9 \text { Other non-metal } \\
\text { mineral products }\end{array}$ & $\begin{array}{c}-0.41 \\
(-0.04)\end{array}$ & $\begin{array}{c}0.25 \\
(1.56)\end{array}$ & $\begin{array}{l}-0.40^{*} \\
(-2.46)\end{array}$ & $\begin{array}{l}0.31^{*} \\
(2.79)\end{array}$ & $\begin{array}{l}0.17^{-10} \\
(0.63)\end{array}$ & $\begin{array}{ll}\mathrm{R}^{2} \mathrm{Aj}=0.18 & \mathrm{~F}(11,59)=0.96 \\
\text { Nobs }=76 & \mathrm{CHISQ}(2)=0.66\end{array}$ \\
\hline $\begin{array}{l}10 \text { Basic metals and } \\
\text { metal products }\end{array}$ & $\begin{array}{c}-0.01 \\
(-1.20)\end{array}$ & $\begin{array}{l}0.52 * \\
(5.36)\end{array}$ & $\begin{array}{l}-0.60 * \\
(-6.50)\end{array}$ & $\begin{array}{l}0.19 * \\
(2.07)\end{array}$ & $\begin{array}{l}-0.80^{-11} \\
(-0.43)\end{array}$ & $\begin{array}{ll}\mathrm{R}^{2} \mathrm{Aj}=0.49 & \mathrm{~F}(11,59)=1.83 \\
\text { Nobs }=76 & \mathrm{CHISQ}(3)=8.19\end{array}$ \\
\hline $\begin{array}{l}11 \text { Machinery and } \\
\text { equipment }\end{array}$ & $\begin{array}{c}0.02 \\
(1.51)\end{array}$ & $\begin{array}{l}0.53 * \\
(5.09)\end{array}$ & $\begin{array}{l}-0.80^{*} \\
(-8.07)\end{array}$ & $\begin{array}{l}0.30^{*} \\
(3.59)\end{array}$ & $\begin{array}{l}-0.99^{-11} \\
(-0.35)\end{array}$ & $\begin{array}{ll}\mathrm{R}^{2} \mathrm{Aj}=0.49 & \mathrm{~F}(11,59)=3.35 \\
\text { Nobs }=76 & \mathrm{CHISQ}(2)=5.51\end{array}$ \\
\hline $\begin{array}{l}12 \text { Electrical and } \\
\text { optical equipment }\end{array}$ & $\begin{array}{c}-0.01 \\
(-0.76)\end{array}$ & $\begin{array}{l}0.41^{*} \\
(4.24)\end{array}$ & $\begin{array}{l}-0.61 * \\
(-5.68)\end{array}$ & $\begin{array}{l}0.56^{*} \\
(4.51)\end{array}$ & $\begin{array}{l}-0.31^{-10} \\
(-0.87)\end{array}$ & $\begin{array}{ll}R^{2} A j=0.71 & F(11,59)=0.87 \\
\text { Nobs }=76 & C H I S Q(3)=0.64^{-01}\end{array}$ \\
\hline $\begin{array}{l}13 \text { Transport } \\
\text { equipment }\end{array}$ & $\begin{array}{l}-0.03 * \\
(-2.55)\end{array}$ & $\begin{array}{l}0.38 * \\
(3.23)\end{array}$ & $\begin{array}{l}-1.04 * \\
(-8.39)\end{array}$ & $\begin{array}{l}0.59 * \\
(8.20)\end{array}$ & $\begin{array}{l}-0.31^{-09} \\
(-1.48)\end{array}$ & $\begin{array}{ll}R^{2} A j=0.82 & F(11,59)=2.04 \\
\text { Nobs }=76 & \text { CHISQ }(3)=14.04\end{array}$ \\
\hline
\end{tabular}

Note. To see Table A1. 
Table A4: Non-EU: National Externalities, International Externalities and Geography

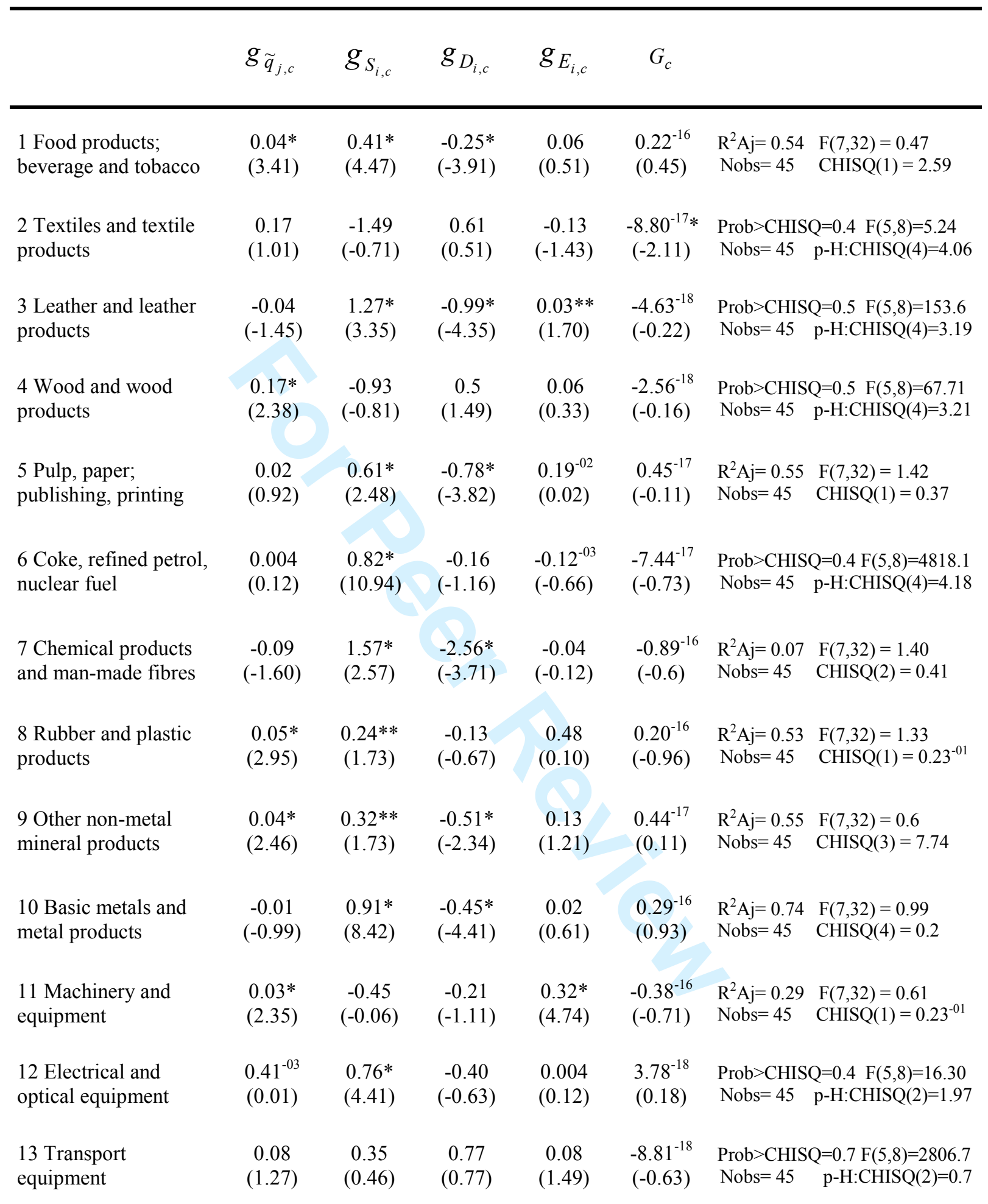

Note. To see Table A1. Non-EU sample: Argentina, China, Costa Rica, Ecuador, Israel, Morocco, Russian Federation, Singapore and Tunisia 